\title{
Analiza uloge gorskog spašavatelja kroz koncept društva rizika: studija slučaja HGSS Stanice Gospić
}

\author{
Anita Bušljeta Tonković \\ Institut društvenih znanosti Ivo Pilar, Područni centar Gospić, Hrvatska \\ e-mail: anita.busljeta.tonkovic@pilar.hr
}

SAŽETAK Svrha ovoga rada jest analiza uloge gorskog spašavatelja u suvremenom društvu rizika, na primjeru HGSS Stanice Gospić. Uz pomoć sociologije rizika kao podloge rada, konkretno teorije o rizičnom društvu (društvu rizika) koje sustavno proizvodi rizična stanja i stvara globalne ekološke opasnosti, te dodatno uz pomoć kombinacije odabranih elemenata teorije mreže aktera zajedno s konceptima solidarnosti i volontiranja tekst pokušava, kroz slaganje svojevrsnog sociološkog bricolagea, zahvatiti dio društvene zbilje s kojom se nosi gorski spašavatelj. Provedbom polustrukturiranih intervjua s narativnim dijelovima u radu su prikazani preliminarni rezultati istraživanja (odnos gorskog spašavatelja, opreme i potražnog psa; kontinuitet i karakteristike djelovanja u društvu rizika; doživljaj akcije - solidarnost; doživljaj vlastite uloge - volontiranje; uloga Stanice i HGSS-a - služenje; širenje djelokruga HGSS-a), koji mogu imati utjecaja na oblikovanje javnih politika, direktno vezanih uz tematiku prebacivanja odgovornosti socijalne države u domenu civilnog sektora. Ukratko, u fokusu ovoga rada je Hrvatska gorska služba spašavanja kao jedan od ključnih aktera sustava civilne zašite, odnosno gorski spašavatelji kao glavni akteri svih potražnih i akcija spašavanja koje se odvijaju na planinskim, ruralnim i slabo pristupačnim područjima.

Ključne riječi: društvo rizika, gorski spašavatelj, HGSS, solidarnost, volontiranje 


\section{Uvod ${ }^{1}$}

Kroz ustroj i djelovanje spasilačkih službi određene države možemo doći do vrijednih saznanja o njezinu društvu i prostoru - prirodnom, ruralnom i urbanom. Fokusiramo li se na istraživanje međuodnosa društvo - spasilačke službe - prostor, utvrdit ćemo određene obrasce djelovanja, točnije politike upravljanja unutar konteksta globalnog društva rizika (Bernstein, 1996., prema Yarwood, 2010.). Na nacionalnim nivoima u europskim državama djeluju brojne službe spašavanja. Najčešće su to službe hitne medicinske pomoći, vatrogasci, specijalizirane vojne jedinice i ostale službe vezane uz koncept civilne zaštite. Unutar tog sustava nalazi se i gorska služba spašavanja ${ }^{2}$. Prostor na kojem primarno djeluje GSS, dakle brdsko-planinski prostor privlačan je planinarima, alpinistima i ljubiteljima adrenalinskih i alternativnih, često ekstremnih sportskih aktivnosti ${ }^{3}$. Taj je prostor privlačan i ostalim posjetiteljima, a dostupan im je, najčešće, tijekom cijele godine. To znači da se nesreće i krizne situacije mogu dogoditi u bilo koje godišnje doba.

Ne postoje jednake nesreće, krize ili katastrofe. Vjerojatnost da se ponovi isti scenarij na istom mjestu minimalna je. Stoga je i pristup u održavanju stabilnosti, odnosno eliminiranju, to jest mitigaciji rizika i rješavanju pojedine nesreće ili katastrofe jedinstven, a uključuje različite kombinacije aktera, vještina i opreme na konkretnom i specifičnom terenu. Složenost procesa održavanja stabilnosti, ali i spašavanja dodatno je uvjetovana društvenim datostima - političkim, društvenim i ekonomskim uvjetima - na nacionalnoj i lokalnoj razini. Stručna znanja i dostupna tehnologija ključan su moment u održavanju stabilnosti, to jest eliminiranju većine rizika. Međutim, kada se dogodi da ta mreža „popuca“, odnosno kada dođe do nesreće, krize ili katastrofe, spasilačke službe vrše specifičnu ulogu, one, naime, „popravljaju, stabiliziraju ili ponovno uspostavljaju" narušenu stabilnost (Yarwood, 2010.:5). Na taj način spasilačke službe, osim što pružaju prvu pomoć unesrećenima, tu pomoć pružaju i sustavu koji se našao u svojevrsnom kolapsu.

Gorska služba spašavanja u Hrvatskoj osnovana je 1950. godine kao služba Planinarskog saveza Hrvatske, članica je ICAR-a (engl. International Commission for Alpine Rescue) od 1992. godine. O važnosti Gorske službe spašavanja u Hrvatskoj, koja 2020.

${ }^{1} \mathrm{U}$ ovom radu predstavljeni su preliminarni rezultati istraživanja koje je provedeno u sklopu projekta 30 godina HGSS Stanice Gospić: Monografija. Projekt provodi autorica rada sa suradnicima tijekom 2020. na Institutu Ivo Pilar. Naručitelj je projekta Hrvatska gorska služba spašavanja Stanica Gospić. Istraživanje je samostalno provela autorica rada. Konačni rezultati istraživanja bit će objavljeni u obliku poglavlja u knjizi 2021. godine.

2 Dalje u tekstu koristit će se i akronim GSS, a za Hrvatsku gorsku službu spašavanja akronim HGSS. 3

3 Ekstremni sportovi kvalificirani su prema okruženju u kojem se aktivnost izvodi, a vezani su uz povećan rizik od ozljede ili smrti, odnosno uz visoku razinu napora pri izvođenju te potrebnu spretnost i koordinaciju (Bąk i Kalina, 2016.). 
obilježava sedamdeset godina od osnutka i koja danas djeluje kroz 25 stanica te broji oko 1000 članova, govori i činjenica da je 2006. godine donesen poseban zakon kojim se uređuje njezin ustroj, djelatnost i financiranje. ${ }^{4}$ Tim zakonom definiran je i sam pojam gorske službe „kao službe koja je osposobljena za spašavanje u planinskom području i na drugim neurbanim i teško pristupačnim područjima pri nepovoljnim vremenskim uvjetima i drugim izvanrednim okolnostima“ (čl. 3). Hrvatska gorska služba spašavanja Stanica Gospić osnovana je 1989., a reaktivirana 2002. godine. Broji tridesetak članova, a odgovorna je za spašavanje na području Ličko-senjske županije i posebno planine Velebit te na području Plješivice, Kapele i Ličkog Sredogorja, što joj daje jednu od ključnih uloga u spašavanju na planinskim i ruralnim prostorima $\mathrm{Hr}$ vatske općenito. Stoga je temeljna svrha ovoga rada analiza uloge gorskog spašavatelja kroz koncept društva rizika uz pomoć studije slučaja HGSS Stanice Gospić.

\section{Teorijska podloga i prikaz osnovnih koncepata}

Temeljna je podloga ovoga rada teorija o rizičnom društvu (društvu rizika). Međutim, korištenjem termina „sociološki bricolage“ u smislu dodatnog pojašnjenja odabira osnovne teorijske podloge, odabira dodatnih koncepata te metoda istraživanja izražava se kompleksnost procesa kojima se pristupilo istraživanoj temi. Kompleksnost tematike zapravo podsjeća na slaganje mozaika od različitih fragmenata i isječaka stvarnosti. Drugim riječima, uz pomoć različitih koncepata, metoda i tehnika kojima se kompletiraju vlastiti uvidi, istraživačica je bila u mogućnosti rekonstruirati kompletnu sliku istraživanog fenomena (Denzin i Lincoln, 2005.; Denzin i Lincoln, 1998., prema Geiger, 2009.).

Urlich Beck koristi se konceptom društva rizika kako bi okarakterizirao moderno društvo kapitalističkog ekonomskog predznaka. Društvo rizika definira u smislu kompleksnog sustava koji se nosi s opasnostima i nesigurnostima, a koje proizlaze iz ukupnog procesa modernizacije (Beck, 1992.). U takvom društvu, svojevrsnom visokosloženom sustavu, i manji poremećaji u funkcioniranju lako dovode do značajnih posljedica (Čaldarović, 1994.). Beck (1992.) smatra kako to društvo obilježava konstantan porast rizika i, posebno, proizvodnja rizika. Tri su njegove osnovne kategorije: a) prirodni rizici (prirodne katastrofe), b) rizici koje je prouzročio čovjek i c) tehnički rizici. Objektivna strana rizika označava postojanje rizika neovisno o tome percipira li se neki pogon ili događaj rizičnim. Subjektivna strana, odnosno socijalna konstrukcija rizika odnosi se na procjenu stupnja samog rizika. Sve spasilačke službe, osobito gorske

${ }^{4}$ Osnovna legislativa vezana uz HGSS: Zakon o Hrvatskoj gorskoj službi spašavanja (2006.), Zakon o izmjenama i dopunama Zakona o Hrvatskoj gorskoj službi spašavanja (2015.), Zakon o sustavu civilne zaštite (2019.), Zakon o sustavu domovinske sigurnosti (2017.), Zakon o udrugama (2014.), Zakon o izmjenama i dopuni Zakona o udrugama (2019.), Zakon o volonterstvu (2013.) i Statut Hrvatske gorske službe spašavanja (2018.). 
službe spašavanja, vezane su jednako uz objektivnu kao i subjektivnu procjenu rizika, u svim trima navedenim kategorijama. Potrebno je imati na umu da se društveno poimanje rizika mijenja, a zajedno s promjenama dolazi do stalnih prilagodbi u radu spasilačkih službi.

Rizik predstavlja procijenjeni stupanj opasnosti, odnosno vjerojatnost nekog nepredvidivog događaja, koji upozorava na mogući opseg njegovih budućih negativnih posljedica za ljude i okoliš. Stoga centar svijesti o riziku nije u sadašnjosti nego u budućnosti (Cifrić, 2012.:324-325). Opasnosti nisu prostorno, vremenski ni društveno ograničene, naime, današnji rizici zahvaćaju cijele zemlje i sve društvene klase, a često prelaze nacionalne granice, pa govorimo o rizicima globalnima po dosegu. Pri tom se osobito misli na oblike proizvedenog rizika, poput onih koji se tiču zdravlja i okoliša (Beck, 1995., prema Giddens, 2007.). Drugim riječima, globalno zatopljenje i, posljedično, ekstremne vremenske prilike te prirodne katastrofe, često uzrokovane antropogenim djelovanjem, predstavljaju globalnu kulisu djelovanja svih spasilačkih službi, pa tako i gorskih službi spašavanja. Zbog toga je jedna od temeljnih zadaća Hrvatske gorske službe spašavanja orijentirana na promicanje zaštite prirode (Statut Hrvatske gorske službe spašavanja, čl. 9). S druge strane, hazardi, opasnosti koje nam prijete i rizici kojima se izlažemo u prirodnom okolišu rezultat su prirodnih procesa poput kretanja vode, odnosno snijega, leda, stijena i kamenja. Ti procesi, između ostalog, rezultiraju snježnim lavinama, poplavama, klizištima, odronima. U planinskim su regijama navedeni procesi, odnosno izloženost rizicima te vrste veći. Općenito, suvremena promišljanja unutar društva rizika polaze od jednostavne pretpostavke: prije nego se krene u obranu od rizika, potrebno ga je osvijestiti, proučiti i, po mogućnosti, što bolje predvidjeti. Ta nova kultura bavljenja rizikom označava svojevrsno upravljanje njime, kroz društvenu, ekonomsku i ekološku perspektivu (Kienholz i sur., 2004.).

Tri su osnovna koncepta, odnosno društvena fenomena koja obilježavaju djelovanje gorskih službi spašavanja diljem svijeta: rizik, volontiranje i solidarnost. Ta ćemo tri koncepta također promatrati kroz teorijsku podlogu društva rizika. Kada je riječ o samom riziku, moguće je govoriti o postojanju određenog broja kvantitativnih zakona u njegovu ispitivanju. Primjerice, ljudi će prihvatiti do tisuću puta veće rizike ukoliko su ih sami odabrali. Prihvatljiva razina rizika stoji u obrnutoj proporciji s brojem osoba izloženih samom riziku. Tolerancija se, dakle, povećava jer se rizik raspodjeljuje na veći broj osoba. Tu se radi o principu podjednake patnje i podjednake izloženosti (rizicima). Istraživanja su također pokazala kako su ljudske reakcije na žrtve katastrofalnih pojava pod utjecajem svojevrsne vremenske kompresije. Drugim riječima, katastrofe „vremenski koncentrirane“ manje se toleriraju od nesreća koje su „vremenski rastegnute“, odnosno čije se posljedice postupno kumuliraju (Krimsky i Goldig 1992., prema Čaldarović, 1994.:213-124).

Suosjećanje i solidarnost temelji su volonterstva. Ono predstavlja „aktivnost koja se poduzima slobodnom voljom pojedinca te osobnim izborom i motivacijom; bez že- 
lje za financijskom dobiti; u organiziranom okruženju (unutar nevladinih udruga, volonterskih centara, manje ili više organiziranih neformalnih skupina); u želji da se pomogne drugim osobama i društvu u cjelini, pridonoseći zajedničkim vrijednostima, bez osobnih interesa [...] “.5 Volontiranje možemo shvatiti kao jedan vid socijalnog uključivanja i integracije. Doprinosi izgrađivanju kohezivnog društva stvarajući veze temeljene na povjerenju i solidarnosti. Na taj način utječe na jačanje ljudskog te unapređenje socijalnog kapitala. Naime, volonteri u svakoj državi predstavljaju ogroman ljudski potencijal koji posjeduje relevantna znanja i vještine korisne za širu zajednicu (Ćulum, 2008.). Volontersko djelovanje kreira prostor u kojem ljudi, bez obzira na nacionalnost, religiju, socioekonomski status i dob, mogu doprinijeti stvaranju pozitivnih promjena u društvu, ono je "navika srca i građanska vrlina“ (Ćulum, 2008.:7). O važnosti volonterstva govori i činjenica da je Sabor Republike Hrvatske usvojio Zakon o volontiranju 2006. godine kao prvi te vrste u ovom dijelu Europe. ${ }^{6}$

Autorice Juzbašić i Vukasović Hlupić (2015.:283) navode ukupno šest motivacijskih funkcija koje se nalaze u podlozi volontiranja. ${ }^{7}$ Funkcionalni pristup u istraživanju motivacije za volontiranjem provjeren je kroz niz od šest znanstvenih studija, kroz različite kontekste i aspekte volontiranja (Clary i sur., 1998., prema Juzbašić i Vukasović Hlupić, 2015.; Miljković i Jurčec, 2015.). Upravo se motiv vrijednosti pokazao kao najvažniji za volontere, bez obzira na spol, dob i kontekst u kojem osobe volontiraju. Odnosi se na altruističnu brigu za druge ljude. Odmah nakon toga nalaze se motivi razumijevanja i poštovanja. Ta dva motiva odnose se na doživljaj novih iskustava, usavršavanje znanja, vještina i sposobnosti, odnosno na potrebu za vlastitim psihološkim rastom i razvojem (Juzbašić i Vukasović Hlupić, 2015.). Istraživanja su, dakle, pokazala kako je volonterski rad koristan ne samo onome kome se tim radom pomaže već i samome volonteru (Miljković i Jurčec, 2015.). Drugim riječima, altruističke aktivnosti poboljšavaju životno zadovoljstvo. Volontiranje je još povezano $s$ različitim pozitivnim ishodima kada je riječ o psihološkoj dobrobiti osobe koja volontira i njezinu zdravlju.

5 Definicija citirana s Europskog portala za mlade: https://europa.eu/youth/hr/article/45/3577 hr (18. veljače 2020.).

${ }^{6}$ Više o temi vidjeti na internetskoj stranici Volontiram Hrvatska!: http://www.hcrv.hr/hv/vazno/ osnovno/o-volonterstvu (18.veljače 2020.).

${ }^{7}$ Funkcija vrijednosti: vezana je uz brigu za druge ljude. Funkcija društva: volontiranje pruža mogućnost društva drugih ljudi i prijatelja te jačanje socijalnih mreža. Funkcija razumijevanja: mogućnost osoba da kroz volonterski rad dožive nova iskustva te priliku da usavršavaju vlastita znanja, vještine i sposobnosti. Funkcija poštovanja: uključivanju u volontiranje radi osobnoga psihološkog rasta i razvoja. Funkcija zašttite: osobe volontiraju radi zaštite vlastitog ega. Funkcija karijere: zadovoljava motive vezane uz dobrobiti koje volonteri dobivaju kroz volonterske aktivnosti, a koje mogu biti važne za buduću karijeru pojedinca (Juzbašić i Vukasović Hlupić, 2015.). 
Autorice Miljković i Jurčec (2015.:117) tu tvrdnju objašnjavaju uz pomoć teorijskog koncepta pristupa sreći. Ne raspravljajući o ugodnom životu, koji odgovara hedonizmu, autorice naglasak stavljaju na angažiran i smislen život: „Angažiran život temelji se na aktivnostima koje nas u potpunosti okupiraju i u koje smo u potpunosti uključeni, dakle na onim aktivnostima koje izazivaju stanje zanesenosti.“ Iz toga proizlazi osjećaj sreće i zadovoljstva. „Smislen život, kao dodatak tome, pretpostavlja korištenje naših sposobnosti i vrlina za nešto što je veće od nas samih - obitelj, zajednica, opće dobro, znanje, pravda i slično." Ukratko, volontiranje je ovdje objašnjeno kao aktivnost koja je „veća od nas samih“, za njezino obavljanje potrebno je biti „potpuno koncentriran i usmjeren“, iz čega proizlazi osjećaj sreće i zadovoljstva. Na takav oblik volontiranja naišli smo i tijekom terenskog istraživanja čije rezultate prikazujemo.

Anthony Giddens (2005.:52) ističe kako život u globaliziranom svijetu predstavlja suočavanje s raznolikošću novih rizičnih situacija. Dodaje kako sve češće umjesto opreza (primjerice pri podržavanju znanstvene inovacije) moramo odabrati hrabrost. Na to zaključuje kako korijen pojma „rizik“ znači „usuditi se“. ${ }^{8}$ Između ostaloga, usuditi se pomoći, riskirati da bismo pomogli, osjećati zadovoljstvo jer smo pomogli. Tu dolazimo do sljedećeg pojma bitnoga za ovaj rad, a to je solidarnost, koja najjednostavnije rečeno označava uzajamnu pomoć (Orlić, 2019.), odnosno stanje u kojem članovi društva imaju određene obveze jedni prema drugima. Tako definirana vezuje se uz koncept ljudskog kapitala, točnije dimenziju norme uzajamnosti (ili reciprociteta). Posljedično se veže i uz ostale dvije (mreže povezanosti i povjerenje) dimenzije ljudskog kapitala (Šalaj, 2007.; Bušljeta Tonković, 2015.). ${ }^{9}$ Taj pojam temelj je suvremenih politika solidarnosti. One čine skup javnih postupaka, akcija i nastojanja kojima se izražava i regulira društvena solidarnost. Kako je rečeno, polaze od pretpostavke da je solidarnost stanje u kojem članovi društva imaju obveze jedni prema drugima. Opseg politika solidarnosti neprestano se širi, isprva su bile shvaćene kao politike popravljanja društvenih rizika, potom su usmjerene k prepoznavanju i prevenciji rizika na nacionalnoj razini. ${ }^{10} \mathrm{U}$ tom se polju javnih politika oblikuje i politika usmjerena na organizaciju i jačanje nacionalnih službi za spašavanje.

Određeni elementi iz teorije mreže aktera također su uporabljeni u kreiranju sociološkog bricolagea ovoga rada. Ukratko, ta teorija istražuje umreženost ljudskih i neljudskih aktera (Yarwood, 2010.; Tabak i Kukić, 2018.). U svojoj suštini proučava načine

8 Rizik (tal. risico) najjednostavnije rečeno označava smion pothvat (Klaić, 1978.).

9 Podsjetimo, pojam solidarnosti u sociologiji se najprije veže uz Émilea Durkheima. Organsku solidarnost pripisuje suvremenim društvima. Jedno od glavnih obilježja tih društava jest specijalizacija zadataka i sve jača društvena diferencijacija. Drugim riječima, podjela rada dovodi do međusobne ovisnosti, jer svatko treba dobra i usluge koje pružaju druge profesije (Giddens, 2007.).

${ }^{10}$ Više o temi vidjeti na internetskoj stranici Hrvatske enciklopedije: https://www.enciklopedija.hr/natuknica.aspx?id=57063 (17. veljače 2020.). 
i uzroke nastanka i održavanja mreža u smislu praktičnog djelovanja (Abercrombie i sur., 2008.). Britanski socijalni geograf Richard Yarwood (2010.:7-8) uz pomoć teorije mreže objašnjava djelovanje gorskih službi spašavanja u Engleskoj i Walesu. Posebnu pažnju usmjerava na razumijevanje odnosa između ljudskih i ne-ljudskih aktera, primjerice čovjeka i potražnog psa. Treći akter od ključna značaja kod istraživanja ustroja i djelovanja (gorskih) službi spašavanja za ovoga je autora suvremena tehnologija. Kao četvrtog aktera Yarwood navodi okoliš. Upravo je poznavanje okoliša, terena na kojem ekipa djeluje od izuzetnog značaja, stoga je važno da se pojedini spasilački tim veže uz konkretan prostor. Ovdje možemo uvidjeti i važnost djelovanja stanica HGSS-a kao organizacija osnovanih upravo na temelju pripadnosti prostoru. Taj prostor spasilačkom timu daje identitet te svrhu postojanja i djelovanja, a daje mu i nezamjenjivo, jedinstveno znanje vezano uz snalaženje na konkretnoj planini, u šumi, selu, gradu, općini. Lokalno znanje, poznavanje mjesta življenja, kulture i uvjeta života spašavatelja čini nezamjenjivim.

Postoji i „nadakter“ koji utječe na djelovanje službi spašavanja, to je širi, nacionalni, regionalni pa onda i lokalni sustav javnih politika. Taj sustav dijelom oblikuje organizacije i ustanove, a igra značajnu ulogu i u dodjeli, odnosno dostupnosti financijskih sredstava pojedinoj službi za spašavanje. Javne politike tako imaju direktan utjecaj na moguće smanjenje rizika, osobito ako u obzir uzmemo pretpostavku da država donošenjem javnih politika i legislative, odnosno doznakom financijskih sredstava prva oblikuje ustroj i rad službi za spašavanje. Sintagma „smanjenje rizika“ usko je vezana uz koncept društva rizika, čiji je jedan od direktnih produkata uspostava službi spašavanja kakve danas poznajemo (Yarwood, 2010.). Ovdje pronalazimo direktnu povezanost teorije o rizičnom društvu s odabranim elementima teorije mreže aktera, a radi se o razumijevanju suodnosa spašavatelj - oprema - potražni pas uz dodatni utjecaj dvaju nadaktera, prirodnog okoliša i uspostavljenih javnih politika.

\section{Metodološka podloga}

U ovom je radu, rekli smo, korišten sociološki bricolage kvalitativnih istraživanja, odnosno mozaik iz kojeg nastaje cjelokupna slika o istraživanoj temi. Sociološki je bricolage u suštini kreacija istraživačice. Takav mozaik predstavlja svojevrsnu kombinaciju različitih interferirajućih, ponekad konkurentskih perspektiva i paradigmi (Denzin i Lincoln, 1998., prema Geiger, 2009.). Slična kombinacija različitih teorijskih pristupa i koncepata predstavljena je unutar prethodnog poglavlja, a dovršena će biti prikazom rezultata terenskog istraživanja.

Najprije je upotrijebljena desk metoda prikupljanja i analize dostupnih izvora literature (Rapley i Rees, 2018.; Murray, 2018.). Potom su uz pomoć metode intervjua, točnije tehnike polustrukturiranog intervjua (s narativnim dijelovima), rekonstruirani događaji, raspravilo se o ključnim momentima, a prethodno su određeni temeljni 
društveni fenomeni na kojima počiva djelovanje Hrvatske gorske službe spašavanja, s naglaskom na Stanicu Gospić. Uz pomoć tematske analize, koja podrazumijeva kategorizaciju podataka u određeni broj tema, odnosno deskriptivnih kategorija, prikazani su rezultati intervjua, obrađeni ručno. Rečeno je kako su na terenu korišteni polustrukturirani intervjui s narativnim dijelovima, u kojima je implementiran isječak life-story protokola. Naime, polustrukturirani intervjui s narativnim dijelovima prilagođeni provedbi s gorskim spašavateljima u Stanici Gospić započeli su s osnovnom uputom koja je glasila: „Zamislite da pišete knjigu o Stanici Gospić, kako bi izgledao popis imena, događaja i akcija?“ (Murray, 2018.). ${ }^{11}$ Na taj je način, uz pomoć osobnog sjećanja i doživljaja članova Stanice Gospić oslikana društvena zbilja djelovanja Stanice i njezinih članova u proteklih 30 godina, i to u smislu vrijednog socijalnog konstrukta (Atkinson, 2002.), što je i bio osnovni cilj istraživanja. Dodatni cilj istraživanja bio je uz pomoć kombinacije saznanja dobivenih uporabom desk metode i rezultata istraživanja prikazati raspravu o potrebi za oblikovanjem novih javnih politika koje će u obzir uzeti izazove s kojima se susreću gorski spašavatelji.

Sam protokol intervjua sastojao se od petnaest pitanja, proveden je tijekom veljače i ožujka 2020. godine s ukupno osam sugovornika, a pratio je sljedeću tematiku: glavni akteri, znanje i vještine, oprema, akcije, infrastruktura, podrška nacionalnih, regionalnih i lokalnih aktera i institucija te podrška obitelji. Djelovanje u društvu rizika, izražena solidarnost i volontiranje članova, koje prelazi u svojevrstan oblik služenja, tri su temelja na kojima smo gradili raspravu tijekom provedbe intervjua; ta su tri društvena fenomena prepoznata i od sugovornika kao ključna.

Posebna pažnja bila je usmjerena prema međuodnosu spašavatelja, opreme i potražnog psa. Ovdje smo pokušali, uz pomoć odabranih elemenata teorije mreže aktera uvidjeti suodnos, to jest umreženost ljudskih i ne-ljudskih aktera, kao i kontinuitet Stanice (koji se veže uz djelovanje na konkretnom prostoru), prema kojem se ona može prepoznati i identificirati/razlikovati od drugih. Tijekom provedbe intervjua pažnju smo obratili i na razumijevanje podrške i prepoznavanja važnosti djelovanja HGSS Stanice Gospić od nacionalnih, regionalnih i lokalnih institucija i drugih aktera, i posebno od članova obitelji gorskih spašavatelja. Naglasak smo stavili i na prepoznavanje važnosti djelovanja Stanice kao i njezin utjecaj na profesionalni i privatni život samog sugovornika. Protokol intervjua zaokružen je dvama pitanjima koja se dotiču osobnog doživljaja. Prvo se odnosi na odabir i opis akcija u kojima je sugovornik sudjelovao a koje su na njega ostavile poseban dojam. Uz pomoć pitanja „Zašto si GSS-ovac?“ dobili smo uvid u osobni doživljaj uloge spašavatelja.

11 Provedbu istraživanja odobrilo je Etičko povjerenstvo Instituta Ivo Pilar dana 20. veljače 2020. godine (Br. 11-73/20-478). 
Sugovornici tijekom provedbe intervjua bili su podijeljeni u dvije skupine. Prvu smo trojicu nazvali Osnivači (naglasak na razdoblje od 1989. do 2001. godine), a ostalu petoricu Reosnivači (naglasak na razdoblje od 2002. do danas). S obzirom na temu istraživanja i doprinos sugovornika u osposobljavanju, odnosno aktivaciji i održavanju kontinuiteta Stanice, identitet će im, uz njihovu (vlastoručno potpisanu) privolu, biti objavljen. ${ }^{12}$ Uzorak je, dakle, bio namjerni. Intervjui su provedeni u Područnom centru Gospić Instituta društvenih znanosti Ivo Pilar, a pojedinačni je intervju u prosjeku trajao 120 minuta. Namjerni uzorak u istraživanju bio je jedini primjenjiv, budući da su konkretne osobe sudjelovale u osnivanju, odnosno reosnivanju stanice. Kontakt s ispitanicima uspostavljen je uz pomoć pročelnika HGSS Stanice Gospić. Svi potencijalni sudionici intervjua odazvali su se pozivu, odnosno nije bilo odbijanja sudjelovanja $\mathrm{u}$ istraživanju. ${ }^{13}$

\section{Analiza $\mathrm{i}$ interpretacija rezultata}

Razvoj tehnologije od 2000-ih godina, odnosno njezina dostupnost širim slojevima društva omogućila je lakše snalaženje u prirodi, ili bolje rečeno omogućila je većem broju stanovništva bezbrižniji odlazak u prirodu pa i u divljinu. Istodobno, razina znanja o snalaženju u prirodi ostala je na istoj, relativno niskoj razini. Osobni lokatori, GPS sustavi, satelitski i mobilni telefoni te sva ostala tehnološka rješenja dala su običnom čovjeku, laiku, priliku da (ponovno) iskusi zov divljine. Primjerice, 2009. godine grupa posjetitelja u Grand Canyonu (na ruti Royal Arch Loop) u Sjedinjenim Američkim državama sa sobom je nosila spomenuti osobni lokator. Tijekom putovanja uređaj su aktivirali tri puta, što znači da su jednako toliko puta zatražili pomoć od spašavatelja. Naposljetku su spašavatelji bili prisiljeni zatražiti ih da napuste područje iz razloga što doprinose stvaranju rizične situacije, odnosno dovode u opasnost sebe i spašavatelje (Cone, 2009., prema Pope i Martin, 2011.). Isti autori kao drugu stranu medalje vide ulogu suvremene tehnologije upravo u pravodobnom spašavanju. Posljedice nepromišljenog korištenja tehnologije vidljive su i kroz povećanje broja akcija gorskih spašavatelja.

Na temelju rečenoga možemo zaključiti da je sve više posjetitelja u planinama, ruralnim i slabo pristupačnim područjima te u nacionalnim i drugim parkovima koji su nesamostalni i neodgovorni. Ujedno su, što je paradoksalno, spremni poduzimati veće rizike, zato što koriste suvremena tehnološka dostignuća za snalaženje u prostoru (Borrie, 2000., prema Pope i Martin, 2011.). Zbog takva trenda dolazi do pojave

12 Identitet sugovornika bit će objavljen u poglavlju knjige. Za potrebe ovoga rada pri citiranju dijelova intervjua navedeni će biti stvarni inicijali konkretnog sugovornika.

13 Jedan ispitanik bio je primoran odustati od sudjelovanja u istraživanju uslijed posljedica pandemije uzrokovane bolešću COVID 19. 
fenomena nazvanog „društvo spašavatelja i spašenih“. Istovremeno, fenomen samospašavanja slabi jer je manje interesa za usvajanje znanja i vještina snalaženja i preživljavanja u prirodi (Hollenhorst 1995., prema Pope i Martin, 2011.). Hrvatska je gorska služba spašavanja jedan od ključnih aktera sustava civilne zaštite, odnosno gorski su spašavatelji glavni akteri u potražnim i akcijama spašavanja u Republici Hrvatskoj, s naglaskom na planinska, ruralna i slabo pristupačna područja. U nastavku slijedi prikaz uloge gorskog spašavatelja kroz studiju slučaja HGSS Stanice Gospić.

\subsection{Gorski spašavatelj, oprema i potražni pas}

Tri su ključna aktera koja se nadopunjuju. Naime, ključni akteri u svim akcijama spašavanja su: spašavatelj koji ima specijalizirana znanja i vještine te vrhunska oprema (prvenstveno suvremena tehnologija). U potražnima akcijama nalazimo i trećeg aktera, radi se o potražnom psu. Ta se tri aktera kombiniraju i ne moraju u svakoj akciji biti od presudnog značenja, međutim moraju u svakom trenutku biti dostupni.

Kada je riječ o tehnologiji, sugovornici ističu tri momenta: komoditet, sigurnost i mogućnost. Komoditet se odnosi na opremljenost Stanice, koja ulijeva dodatnu sigurnost spašavateljima, to dvoje rezultira mogućnošću da spašavatelji tijekom akcije koriste resurse koji im olakšavaju rad. Premda imaju dostupnu vrhunsku opremu i tehnologiju, nikako ne smiju biti ovisni o njoj:

Oprema je vrlo bitna, pogotovo današnja tehnologija, digitalna oprema, IT oprema; to je naš možda najjači adut, to što mi imamo najsuvremeniju opremu. Bez opreme se ne može, ali oprema je alat, najvrjednije u GSS-u su ljudi. J. B.

Naime, u svakom trenutku neka vrsta opreme ili tehnologije mogla bi zakazati. Zbog toga svaki spašavatelj mora usvojiti znanja i vještine spašavanja. Četiri osnovna tečaja, konstantne edukacije i vježbe uz pomoć kojih usavršavaju znanja i vještine, spašavateljima služe da budu sposobni „raditi na palentu“ (T.R.), da budu „majstori improvizacije“ (T.R.). Ono što spašavatelji moraju znati, dakle osnovna, bazična znanja koja su usvojili na spomenutim četirima tečajevima - ljetnom, zimskom, speleospašavanju i medicini gorskog spašavanja - osnova su koja mora stajati, jer „to mora biti bez greške; jedna greška i nema ispravka“ (T.R). Sugovornici ističu da bi pri izboru između iskustva, poznavanja terena i opreme najprije dobro razmislili, ipak, poznavanje terena i iskustvo bi prevagnuli.

Ništa manje nije bitna nadogradnja. Ona gorskog spašavatelja obilježava, usmjerava ga prema onoj vrsti uže specijalizacije za koju ima veće sposobnosti ili dodatno usavršava znanja i vještine koje je već usvojio na radnom mjestu. Ponekad su određena znanja i vještine pojedincu bile hobi, koji je onda dobio priliku u GSS-u usavršiti i na taj način postati spašavatelj specijaliziran za neko područje. Stečena znanja spašavatelji među- 
sobno dijele, na taj način prikupljaju ideje uz pomoć kojih se ljudski kapital unutar Službe nadograđuje.

Paralelno s usvajanjem znanja, vještina, upoznavanjem opreme i njezinom uporabom, odnosno zajedničkim odlaskom u akcije nastaje specifičan oblik prijateljstva. Izgradnja povjerenja i stvaranje prijateljstva, uz strogo uvažavanje pravila i uporabu suvremene tehnologije posebno vrijedi kada društvenog aktera ne čini samo čovjek. Naime, nakon što je Stanica Gospić dobila prvog gorskog spašavatelja, drugi po redu koji je dobio licencu za spašavanje bio je njemački ovčar Aron. Međuodnos čovjeka, psa i suvremene tehnologije danas je postao sastavnim dijelom potražnih akcija. Pas u ovom slučaju predstavlja dio tima, a međusobni odnos čovjeka spašavatelja i psa spašavatelja temelji se na čvrstom povjerenju.

Ja i pas činimo tim. [...] Živišs tim psom, on je kod tebe, ti si svaki dan s njim. Taj pas je kućni ljubimac, ali on je i radni stroj. Ti kad ideśs [u akciju], on je radni stroj [...]. On tebi pomaže, vas dva se morate poznati i jedan drugom vjerovati. Psa tokom obuke nikad ne lažeš [...]. Uvijek mora biti povjerenje izmedu čovjeka i psa. Jako veliko povjerenje. M. J.

\subsection{Gorski spašavatelj, rizik, solidarnost i volontiranje}

Tri su društvena fenomena na kojima počiva rad gorskih službi diljem Europe i svijeta. Sugovornici se slažu da su to djelovanje u društvu rizika, odnosno poseban vid nošenja s rizikom, solidarnost i volontiranje. Sugovornike smo pitali kada postaju svjesni, odnosno razmišljaju li o tome da u određenom momentu snose odgovornost za vlastiti i posebno za život osobe koju najčešće uopće ne poznaju. U trenutku odlaska u akciju nemaju vremena promišljati o rizicima kojima bi mogli biti izloženi. O rizicima i opasnostima raspravljaju naknadno, kada vrše analizu okončane akcije. Ističu kako je jedina proračunatost u vremenu od dojave do odlaska u akciju ona kako što prije doći do unesrećenog. Misli im zaokuplja pitanje što ponijeti, odnosno kakva im je oprema potrebna te kako pristupiti ozlijeđenom s obzirom na njegovu ozljedu. Objektivna je strana rizika, bez obzira na pojedinačnu situaciju, umanjena zbog strogih propisa i pravila koje spašavatelji slijede prilikom odlaska i tijekom akcije. Međutim, kako se najčešće radi o hitnim slučajevima, nemoguće je izbjeći izlaganje određenim rizicima poput sudjelovanja u prometu ili kretanju po opasnom i nepristupačnom terenu.

Kao jedan od načina smanjenja potencijalnih rizika spašavatelji navode važnost uskih specijalizacija spašavatelja, odnosno raznolikost struka kojima se bave u profesionalnom životu ili pak kroz hobije. Uz to, kao osnovnu podlogu smanjenja rizika vide poznavanja terena/okoliša: 
Poznavanje terena, i to ponovno vezujem uz iskustvo i planinarenje, jer ne možeš poznati teren ako ga nisi prošao. Uzalud tebi stotinu GPS-ova ako ti ne’ko reče da je na Aginom kuku, a'j ga ti nadi!' J. T.

Rečeno se posebno odnosi na samo gorsko spašavanje, gdje svi ispitanici zaključuju da je prethodno bavljenje planinarenjem (bio njihov) ključan moment za pridruživanje HGSS-u. Posljednjih se godina Stanici Gospić priključuju mladi ljudi koji prethodno nemaju iskustva u planinarenju, međutim, ono ubrzo postane dio njihova načina življenja, jer shvate da su planinarenje i aktivan angažman u gorskom spašavanju jedno $s$ drugim usko vezani. Osobito je to važno zbog "planinarskog načina razmišljanja“, odnosno viđenja prostora. Naime, Gorska služba svoje korijene vuče upravo iz planinarenja, a sva četiri tečaja uz pomoć kojih se postaje gorskim spašavateljem vezana su uz planinski prostor. Jedan od razloga dolaska mladih spašavatelja koji prethodno nisu imali iskustva u planinarenju i ostalim aktivnostima na planini članovi vide $u$ tome što takve aktivnosti nisu dovoljno promovirane, uz to oprema za bavljenje tim aktivnostima često iziskuje dodatne materijalne troškove. Napominju da je stanicama HGSS-a u većim gradovima lakše doći do iskusnih ljudi koji će postati pripravnici nego je to slučaj u manjim, ruralnim sredinama, koje općenito u Hrvatskoj obilježavaju depopulacijski procesi.

U GSS se ulazi... moraš biti dobar, da ne kažem sad istaknut u nekoj specijalnosti: speleologiji, alpinizmu, sportskom penjanju, skijanju ili medicini... U velikim gradovima, u nekim većim stanicama možeš uzimati najbolje ljude iz takvih klubova, a na preporuku predsjednika kluba. U Gospiću nije bilo ništa takvo, bilo je jedino planinarsko društvo. J. B.

Smanjenju rizika, smatraju sugovornici, uvelike doprinosi međusobno povjerenje, koje se gradi postupno, kroz usvajanje znanja, vještina, kroz interakciju i suradnju. $\mathrm{Na}$ tim temeljima onda nastaje i specifičan oblik prijateljstva. Jedan od sugovornika to prijateljstvo naziva „ekipa“, dok ga drugi poistovjećuje s obitelji:

Meni je kljucna ekipa. To je meni bitna stvar. Jer ako mi znamo svi tehniku, ako svi navežemo sve, ako ja znam kako ti misliš, kako razmišljaš i što si ti sposoban napraviti $i$ ti dobiješ neki zadatak, ja imam drugi zadatak. Ja ne moram tebe provjeravati, ni ti mene. To je ekipa, ako imaš povjerenje u ekipu, onda imaš sve. J. T.

Mi smo stvarno jedna velika obitelj. Mi svi pazimo jedan na drugog jer idemo i spašavamo tude živote, onda normalno da moramo paziti i na svoje. M. J.

Ovdje bismo ekipu mogli odrediti u smislu članova jedne Stanice, dakle takva ekipa počiva na međusobnom uvažavanju koje proistječe iz usvojenih znanja i vještina. Znanja i vještine pak jačaju $s$ vremenom i stečenim iskustvom. To dvoje jača povjerenje 
unutar Stanice. Povjerenje i iskustvo ujedno daju osjećaj sigurnosti. Sve zajedno sačinjava specifičan društveni kapital (norme uzajamnosti, mreže povezanosti i povjerenje) na mikrorazini, dakle u samoj Stanici. Takav se obrazac, najvjerojatnije, prelijeva i djeluje unutar cjelokupne organizacije. Kada ekipa posjeduje navedene odlike, razina se objektivnog, a pogotovo subjektivnog doživljaja rizika smanjuje, smatraju sugovornici.

Dolazimo do druga dva momenta o kojima valja raspraviti. Prvi je solidarnost. Ona se najprije događa unutar Gorske službe i posebno unutar i između samih Stanica. ${ }^{14}$ Tome svjedoči razina solidarnosti koju su stanice Gorske službe pokazale u trenutku kada se, 2000-ih godina, ponovno aktivirala Stanica Gospić. Lokalnoj se zajednici Stanica Gospić u to vrijeme nije imala čime predstaviti. Bez opreme, znanja i vještina, bez provedene akcije spašavanja, članovima stanice ostajala je samo dobra volja da postanu gorski spašavatelji. U tim trenucima s njima su opremu i znanje podijelile ostale stanice HGSS-a, te su im na taj način pružile prijeko potrebnu podršku. Gospićki gorski spašavatelji posebnu zahvalnost osjećaju prema HGSS Stanici Karlovac. Spašavatelji iz te stanice bili su mentori gospićkim spašavateljima i prvi s kojima su uspostavili ozbiljniju suradnju.

Solidarnost prema članovima lokalne zajednice, osim kroz potražne i akcije spašavanja, vidljiva je kroz humanitarne akcije koje gorski spašavatelji provode ili se na njih odazivaju. Jedna takva u Stanici Gospić trajala je nekoliko godina. Bila je to jedna od prvih aktivnosti nakon reaktivacije. Članovi Stanice pomagali su starici koja je tijekom zime zbog neizgrađenosti cestovne infrastrukture ostajala odsječena od ostatka svijeta u jednom ličkom zaseoku podno Velebita.

Dosada smo pažnju usmjerili prema pitanju kako se gorski spašavatelji nose s rizikom. Ovdje treba istaknuti kako se misija HGSS-a ponajprije odnosi na njegovu prevenciju $\mathrm{i}$, ako se rizična situacija dogodi, na smanjenje posljedica te situacije. U trenutku kada se dogodi nesreća spašavatelji ne misle o riziku za vlastiti život, nego misle o riziku u kojem se nalazi život koji spašavaju. Za strah kažu kako ga „imaju svi, prirodan je strah u ljudima, ali bitno da ga nemaš panično“ (J.B.). Rekli smo da je solidarnost u suštini stanje u kojem članovi društva imaju obveze jedni prema drugima. Gorski je spašavatelj osjetio tu obvezu nešto snažnije. Na pitanje zašto osjećaju obvezu pomaganja, odnosno kakva je to potreba da spase drugoga, koji je najčešće potpuni stranac, sugovornici odgovaraju da im je to najprije bio izazov, nakon toga su shvatili da mogu (nekoga spasiti), a potom su imali potrebu dati dio sebe za takav (plemenit) cilj.

${ }^{14}$ Kada govorimo o solidarnosti, potrebno je napomenuti da HGSS ne funkcionira strogo teritorijalno. Premda svaka stanica primarno djeluje na određenom prostoru, čim se procijeni da nema dovoljno resursa, u konkretnu se akciju pozivaju druge stanice, prvo one susjedne, a ako je potrebno, onda u pomoć stižu stanice iz cijele Hrvatske. 
Solidarnost, potrebu pomaganja drugome ovdje smo vezali uz volonterski rad. Volontiranje u osnovi znači dobrovoljno ulaganje vremena, truda, znanja i vještina. Rezultat takva djelovanja jest dobrobit druge osobe ili zajednička dobrobit. Sugovornici se slažu kako sam pojam volontiranja u vrijeme kada oni reaktiviraju Stanicu Gospić, dakle početkom 2000-ih, nije bio u fokusu javnosti niti su oni tom pojmu davali osobito značenje. ${ }^{15}$ Volontiranje u Stanici vezuju uz prijateljstvo i obvezu pomaganja drugima. Dakle, volontiranje kao pojam i društveni fenomen u svome djelovanju ne stavljaju na prvo mjesto. Uz to, ističu kako vrijeme koje provode u ulozi gorskih spašavatelja premašuje okvire volonterskog rada. Zbog toga njihova aktivnost predstavlja svojevrstan hibrid između volontiranja i određenog stila života, a pojam volontiranja najčešće zamjenjuju pojmovima služenja i dobrovoljstva. Zbog toga pristaju na zaključak kako njihov doživljaj volontiranja odgovara aktivnosti koja jest veća od njih samih. Slažu se s tvrdnjom da u obavljanju ovoga vida volontiranja moraju biti potpuno koncentrirani i usmjereni, a kao finalni produkt dobiju poseban doživljaj sreće i zadovoljstva.

\subsection{Gorski spašavatelj i služenje zajednici}

Na pitanje što bi mogli izdvojiti kao kontinuitet Stanice, moment koji je pozitivan i stalno se ponavlja, sugovornici se slažu da je to ponos. Ponos jer smo "sve spasili“ (T.R.) i ponos „jer smo opstali“ (A.Z.):

Mi smo imali tu sreću, do sada, znači kome god smo pružili pomoć, one koje smo zatekli žive, da smo ih žive dopratili do hitne, do bolnice. Naš taj dio, zbrinjavanje i transport je prošao besprijekorno. Osim što smo im pomogli, zbrinuli ih, doveli smo ih do sigurnih ruku. Uglavnom, to mi je ono, stvarno mi je to velika stvar. T. R.

Sugovornici ponos opisuju na jedan specifičan način; on nastaje kao konačan rezultat akcija, a direktan je produkt hrabrih poduhvata, taj je ponos sličan onome vojničkom. „Ponos jer su opstali“ navode u smislu kontinuiteta članstva u HGSS-u. Naime, 2019. godine Stanica Gospić obilježila je tridesetu godišnjicu od osnutka. Sugovornici još smatraju da njihovu Stanicu obilježava predani rad, želja za usvajanjem znanja i entuzijazam. Tome dodaju vještine i sposobnosti spašavatelja, odnosno složenost akcija koje su uspješno priveli kraju.

Najteže akcije u GSS-u, odnosno u Hrvatskoj su naše akcije. Mi imamo to nekakvo područje; kao županija držimo 11\% teritorija RH i uvijek su akcije o kojima se priča, najteže akcije su kod nas. A. Z.

Po pitanju suradnje s lokalnom zajednicom, lokalnom i regionalnom upravom, sugovornici smatraju da je ona vrlo dobra. Ponekad oduzima i više vremena nego ga gorski

15 Prvi hrvatski Zakon o volonterstvu Sabor je usvojio tek 2007. godine. 
spašavatelji imaju. Razlog vide u tome što su se u proteklih dvadeset godina pozicionirali kao uspješna udruga civilnog društva, odnosno uspješna Stanica HGSS-a. Stoga su postali poželjan partner u projektima razvoja zajednice i društva. Podršku i suradnju s akterima u lokalnoj zajednici gorski su spašavatelji pravdali najprije uspješnim ekspedicijama, a potom uspješnim i profesionalno obavljanim akcijama.

Nikad nam nije falilo novaca i nikad nam nitko nije zatvorio vrata. Mi smo bili neki dobri dečki iz ovoga grada, koji se s tim bave, i ono, „svaka čast, pomoći ćemo vam, čuvajte se". I sad, uspon na Mont Blanc, bilo je loše vrijeme, odustajalo se. Svi su se vraćali. Mi nismo išli stazom, nego smo rubili dole da nas vjetar prebacuje, pa smo rubili ispod planine, ispod ruba leda da bi došli do vrha $i$ onda smo se slikali. Kad bi izvadio ruku iz rukavice i poslikao, ne bi je moga više vratiti nazad. Ali stalno M. S̆. nešto traži i na kraju izvadi zastavicu Grada. Znači, nismo se mogli vratiti, odustati nego smo riskirali život, jer smo obećali se popeti. Taj osjećaj odgovornosti, da nešto vratimo u ovaj grad je zapravo bilo nešto o čemu smo mi tad pričali. To je bila tema razgovora jer smo se predomišljali izmedu alpinističkog kluba i GSS-a. Ali prevagnuo je GSS jer smo smatrali da smo to dužni, a mi ćemo i kroz GSS moći penjati. A. Z.

Obitelji gorskih spašavatelja njihovo aktivno sudjelovanje u Gorskoj službi doživljavaju na sljedeći način. Radi se o osjećaju straha i neizvjesnosti, odricanju i kompromisu $s$ jedne strane te bezuvjetnoj potpori i ponosu s druge. Osjećaji su, dakle, podijeljeni, međutim spašavatelji smatraju da na kraju prevagnu ponos i potpora, jer da nije tako ne bi ni mogli (p)ostati GSS-ovci.

Posljednje pitanje tijekom provedbe intervjua bilo je „Zašto si GSS-ovac?“. Odgovore možemo sažeti u dvije kategorije. Prva se odnosi na shvaćanje članstva u HGSS-u kao dijela identiteta.

Il'si taj il' nisi taj. Mi se ne bavimo GSS-om nego mi živimo GSS. Ja tako živim. Baviš se GSS-om? Ne. A kako ćešs se baviti?! Baviš se nogometom, ideš igrati kad ti se rači. Ako živiš GSS, tako i kod kuće složiš. Digneš se od ručka, i po noći, i ono, kad zove, zove. Zato, il' si taj il' nisi taj. M. J.

Druga kategorija odnosi se na shvaćanje članstva u HGSS-u kao poziva za služenje drugome, odnosno zajednici.

Zbog želje da pomognem unesrećenoj osobi svim svojim znanjem, iskustvom i sposobnostima, i zbog toga što sam onda vidio da se ja kao takav osjećam bolje. Evo, da sam ono, možda je glupo reći, bolji čovjek. Sam sebi se osjećam vrjednije, korisnije. J. B.

Rečeno je da aktivno članstvo u Gorskoj službi vodi prema jačanju ljudskog i društvenog kapitala. Odlasci na tečajeve, susreti s ljudima različitih ekspertiza, s pojedincima 
iz drugih dijelova Hrvatske i Europe, sve to utječe na osobno iskustvo - gorski spašavatelj širi poznanstva, upoznaje druge krajeve i mjesta, susreće se s novim kulturamašto dovodi do razmjene (ne)formalnih znanja i informacija. Nije ovdje isključivo fokus na širenju osobnih poznanstava, znanja i vještina, već se radi o širenju potencijalnih mreža za profesionalnu, odnosno suradnju unutar i između gorskih službi spašavanja. Na taj način gorska služba uistinu služi kao rezervoar znanja, vještina, ideja, entuzijazma, prijateljstava i profesionalne suradnje. Ukratko, gorska služba upotpunjuje spašavatelja na osobnom planu i posebno kao stručnjaka, a on istodobno obogaćuje stanicu kojoj pripada. Na taj se način prožima i povezuje ljudski s društvenim kapitalom. $\mathrm{O}$ tome svjedoče i sugovornici:

Zahvaljujući mome prvom psu, to je bila kuja Tai, belgijski ovčar, ja sam uśao u Komisiju za potrage, zahvaljujući tome sam postao član izvršnog odbora, a zahvaljujući tome postao $i$ dopročelnik HGSS-a; zahvaljujući svemu navedenom ja sam prošao gotovo sve zemlje Europe, a u nekima sam bio više puta. Bio sam i u Americi. To je svakako utjecalo na mene, izgradilo me kao nekog drugog čovjeka. Odnosno dalo mi je mogućnost da neke stvari sagledam na način kako to gledaju neki drugi narodi, da vidim kako se neke stvari odvijaju u drugim državama, drugim nacijama. A. Z.

Gorska služba svojim članovima omogućuje usvajanje određene količine ljudskog i društvenog kapitala, međutim „GSS uzme puno života“ (A. Z.). Drugim riječima, osim što postane dio njihova identiteta, Gorska služba, smatraju sugovornici, (od) uzima neke životne trenutke koje „obični ljudi“ uzimaju zdravo za gotovo. Zbog toga valja zaključiti da GSS oblikuje dio identiteta gorskog spašavatelja, ali taj dio u najvećoj mjeri i prisvaja.

\section{Rasprava}

\subsection{Gorski spašavatelj u kontekstu širenja djelokruga HGSS-a}

Kao neke od osnovnih karakteristika timova gorskih spašavatelja autori Yarwood (2010.) i Nichols i sur. (2014.) navode izražen osjećaj samostalnosti, timski rad, disciplinu, odanost te izražen osjećaj privrženosti i prijateljstva. Isti autori navode čak i posebnu vrstu socijalizacije kroz koju prolaze novi članovi koji uče kako se nositi sa situacijama životne ugroze. $\mathrm{O}$ tome svjedoče i rezultati u ovom radu prikazanog istraživanja. Gorska služba spašavanja, čiji su članovi volonteri, u stalnoj je interakciji s ostalim spasilačkim službama (prvenstveno sa službom hitne medicinske pomoći, policijom i vatrogascima). Za razliku od gorske službe, koja jest dijelom financirana iz državnog proračuna, ali se nalazi u domeni civilnog društva, a odlikuje je volontiranje, ostale službe kao dio državnog ustrojstvenog tijela podrazumijevaju zapošljavanje svojih članova. 
Britanski su autori Nichols i sur. (2014.) istražili takve interakcije, a fokus istraživanja stavljan je na sve učestalije korištenje usluga gorske službe spašavanja za potrage koje nisu vezane uz gorski i planinski prostor. Na taj način, rečeno je, gorska služba imala je češće kontakte s policijskim i ostalim službenicima te je trošila veći udio vremena na akcije koje su, kako spomenuti autori kažu, iz nadležnosti policije polako prešle u civilnu domenu. Ovdje se, uz pomoć novooblikovanih solidarnih politika, dodatna odgovornost pokušava prebaciti na civilni sektor, odnosno dolazi do ponovne promjene odnosa na relaciji javni - civilni sektor. Moglo bi se reći kako takva praksa jest zakonski regulirana, služi općem dobru i vid je solidarnosti prema svim članovima društva, međutim Nichols i sur. (2014.) ističu kako takvi zahtjevi utječu na spremnost za volontiranjem, jer gorske su službe prvotno uspostavljene upravo kao službe spašavanja čiji su članovi planinari-volonteri, a osnovna im je zadaća bila pomoć i spašavanje u brdsko-planinskim područjima. U međuvremenu se mijenja stupanj prihvatljive razine rizika u društvu. Slijedom toga procesa dolazi do promjene legislative, odnosno dolazi do proširenja područja djelovanja gorske službe.

Autori Šuperina i Pogačić (2007.:236) upravo na tragu gore navedenog istražuju koliko je Hrvatska gorska služba spašavanja uključena u traganje za nestalim osobama, $s$ posebnim fokusom na akcije koje donedavno nisu bile u domeni HGSS-a. Naime, tijela državne uprave, poglavito policija, sve su više orijentirana na suradnju s udrugama građana po pitanju ostvarivanja kolektivne i individualne sigurnosti građana i njihove imovine. Jedna od takvih udruga je i Hrvatska gorska služba spašavanja. Zaključuju da je za svako krizno stanje potreban poseban scenarij kako bi se upravljalo i ovladalo krizom. Međutim, ni najbolji scenariji ne vrijede ako se ne ovlada vještinama njihove realizacije. Sustavi sigurnosti, zaštite i spašavanja najčešće ne mogu samostalno i bez suradnje ovladati nastalom situacijom. Naime, za uspješnu koordinaciju u kriznim stanjima, odnosno za uspješno rješavanje nastalog problema moraju postojati timovi koji će zajednički i koordinirano voditi igru. U njihovom sastavu trebaju biti najsposobniji pojedinci. Dio takvih timova svakako su i pripadnici HGSS-a, koji se konstantno školuju, odnosno usavršavaju svoje vještine. Na taj način predstavljaju neizostavnu kariku suvremenih sustava zaštite i spašavanja, a uvelike pridonose i sustavu sigurnosti. ${ }^{16}$

Država sve manje sredstava, opreme i mogućnosti za edukaciju omogućuje djelatnicima službi koje su odgovorne za potrage i spašavanja. Država blagostanja ili socijalna država slabi, a sve više odgovornosti prebacuje se na civilno društvo. U tom je smislu određeni dio odgovornosti prebačen i na Gorsku službu spašavanja. To znači da gorski

16 Na tu temu i slovenski autori Prebilič i Svete (2020.) ističu kako su članovi slovenske gorske službe, zbog svojih specifičnih znanja i vještina, nezamjenjivi u misijama spašavanja, koje često nemaju veze sa spašavanjem u planini. Navode primjere spašavanja s visokih zgrada ili gradilišta, a kao glavni razlog involviranja gorske službe u te misije navode profesionalnost, pouzdanost i brzu reakciju gorskih spašavatelja. 
spašavatelj osim u planini i na nepristupačnim, ruralnim prostorima sada spašava i u gradovima, na vodi, traži nestale osobe; širi se djelokrug njegova rada i posljedično odgovornosti. Danas je HGSS dio sustava Civilne zaštite te podliježe Zakonu o sustavu civilne zaštite, koji je Hrvatski sabor prvi put usvojio 2015. godine. Prema tom Zakonu Gorska služba označena je kao jedna od operativnih snaga sustava civilne zaštite, zajedno s Vatrogastvom i Crvenim križem. Stoga je širenje djelokruga Službe zapravo određeno zakonskom regulativom. Na taj način HGSS (p)ostaje jedina služba koja je odgovorna za specifične vrste potraga i spašavanja, osobito ako se radi o spašavanju u ekstremnim uvjetima ili na nepristupačnom terenu.

\subsection{Izazovi i budućnost moralnog lika gorskog spašavatelja}

S obzirom na sve veći broj intervencija kao i širenja djelokruga HGSS-a u Hrvatskoj, potrebno se zapitati s kojim se izazovima ova organizacija već sada susreće. ${ }^{17}$ Dva su osnovna izazova o kojima bismo mogli raspravljati. Prvi se odnosi na dilemu oko profesionalizacije Gorske službe ili njezina daljnjeg razvoja u sklopu civilnog sektora. Drugi se, za očekivati je, odnosi na način financiranja Službe. Je li moguće održati financijski moment Gorske službe kakav je bio do sada, dakle financiranje iz proračuna i donacija, ili je tome potrebno dodati naplatu određenih vrsta potraga i spašavanja? $\mathrm{U}$ prilog potonjem ide i činjenica da velik broj potraga više nije vezan uz spašavanje u planinama. Gorska služba, koja je nastala iz Hrvatskog planinarskog društva s osnovnim ciljem da opremljeni i uvježbani planinari pomognu ostalim planinarima u nevolji, u protekla je dva desetljeća učinila odmak od svoje početne misije. Mogli bismo reći kako danas služi široj zajednici, a mogli bismo također reći da zajednica postaje sve više zahtjevna i sve manje odgovorna za posljedice vlastitih ponašanja.

Zašto je tome tako? Suvremeni su životni stilovi često vezani uz stresne situacije, poglavito na radnom mjestu, što iziskuje potrebu za kanaliziranjem toga stresa. Kanali za rješavanje stresa sve se više pronalaze u ekstremnim, adrenalinskim sportovima i aktivnostima na otvorenom. Spašavanje unesrećenih vezano uz te aktivnosti često iziskuje više resursa nego je to slučaj kod, nazovimo, klasičnog spašavanja u planini. S obzirom na širenje djelokruga Gorske službe, spašavatelji provode sve više vremena u akcijama spašavanja, na vježbama, obukama i treninzima, odnosno usavršavanjima svojih vještina. Utječe li to na motivaciju gorskog spašavatelja ili, bolje rečeno, utječe li to na njihovu brojnost? Stanica Gospić 2019. godine prvi je put u povijesti HGSS-a raspisala oglas u kojem je tražila da se jave potencijalni kandidati za gorskog spašavatelja.

17 Odlomci koji slijede nastali su na temelju rezultata ovog istraživanja i posebno uz pomoć promišljanja slovenskih autora Prebiliča i Svete (2020.) u tekstu „New Challenges and Possible Reorganization of Slovenian Mountain Rescue Service". 
U raspravi o izazovima s kojima se HGSS susreće postoje dva osnovna scenarija za budućnost. Prvi je da način pružanja besplatne pomoći ostane isti ili sličan sadašnjem, da organizacija dalje nastavi na temeljima volonterstva, odnosno dobrovoljnog rada i civilnog ustroja. Drugi se odnosi na daljnju institucionalizaciju i profesionalizaciju Službe, gdje bi misija gorskog spašavatelja postala profesija, a spašavanje i dalje besplatno. Međutim, postoji i treći, hibridni scenarij. U slučaju (polu)profesionalizacije država preuzima financiranje Službe, a taj je izdatak znatno veći od dosadašnjeg. Takav scenarij najvjerojatnije pretpostavlja uvođenje naplate određenih tipova spašavanja.

Što će se dogoditi ako se Gorska služba profesionalizira, ako misija gorskog spašavatelja postane radni zadatak? Slovenski autori Prebilič i Svete (2020.) po tom pitanju navode sljedeće. Dobro plaćen posao i strogo određena pravila, odnosno najkvalitetnija oprema, učestale i stručne edukacije, najzahtjevnije obuke i treninzi možda ne budu dovoljno. Naime, gorski spašavatelji mora najprije voljeti ono što radi i mora uživati u planinarenju. Osobito stoga što tijekom procesa spašavanja spašavatelj osjeća veliko fizičko opterećenje kao i psihički pritisak. Gorski je spašavatelj prema tome akter koji riskira cjelokupan osobni integritet da bi spasio nečiji život. Tu je vidljiva posebnost djelovanja gorskog spašavatelja, moment koji po svojoj naravi nadilazi profesiju, a koji sugovornici istraživanja u ovom radu nazivaju moralnim likom spašavatelja.

\section{Zaključak}

Hrvatska je gorska služba spašavanja jedan od ključnih aktera sustava civilne zaštite, odnosno gorski su spašavatelji glavni akteri u potražnim i akcijama spašavanja u Republici Hrvatskoj, s naglaskom na planinska, ruralna i slabo pristupačna područja. HGSS Stanica Gospić, koja je osnovana 1989., a reaktivirana 2002. godine, odgovorna je za spašavanje na području Ličko-senjske županije i posebno planine Velebit te na području Plješivice, Kapele i Ličkog Sredogorja, što joj daje jednu od ključnih uloga u spašavanju upravo na navedenim prostorima.

Tri su osnovna koncepta, odnosno društvena fenomena koja obilježavaju djelovanje gorskih službi spašavanja diljem svijeta: rizik, volontiranje i solidarnost. Također su tri ključna aktera koja se nadopunjuju kod svih potražnih i akcija spašavanja gorske službe: spašavatelj, koji ima specijalizirana znanja i vještine, vrhunska oprema i potražni pas. U ovom su radu, koji je nastao uz pomoć teorije o rizičnom društvu, elemenata iz teorije mreže te posebno kroz perspektivu triju spomenutih fenomena, a promatrajući ključne aktere koji djeluju pri Gorskoj službi spašavanja na konkretnom prostoru Ličko-senjske županije, doneseni sljedeći zaključci. Djelovanju u kontekstu društva rizika, konkretno smanjenju rizika doprinosi povjerenje među gorskim spašavateljima koje nastaje unutar Stanice, a gradi se postupno, kroz usvajanje znanja, vještina te kroz interakciju i suradnju. Na tim temeljima onda nastaje i specifičan oblik prijateljstva. Solidarnost je razvijena unutar Gorske službe i posebno unutar i između samih Stanica. Dodatno, solidarnost prema članovima lokalne zajednice, osim kroz potražne i 
akcije spašavanja, vidljiva je kroz humanitarne akcije koje gorski spašavatelji provode ili se na njih odazivaju. Volontiranje u Stanici Gospić gorski spašavatelji vezuju uz prijateljstvo i obvezu pomaganja drugima. Volontiranje kao pojam i društveni fenomen u njihovu djelovanju nije postavljen na prvo mjesto jer vrijeme koje provode u ulozi gorskih spašavatelja premašuje okvire volonterskog rada. Zbog toga njihova aktivnost predstavlja svojevrstan hibrid između volontiranja i određenog stila života, a pojam volontiranja najčešće zamjenjuju pojmovima služenja i dobrovoljstva. Prihvaćanje rizika, jačanje solidarnosti, služenje zajednici i dobrovoljstvo kod pripadnika Stanice dovode do osjećaja ponosa, koji nastaje kao konačan rezultat akcija, a taj je ponos sličan onome vojničkom. Obitelji gorskih spašavatelja, zbog njihova aktivnog sudjelovanje u Gorskoj službi, osjećaju strah i neizvjesnosti, naviknuti su na odricanje i kompromis, ali jednako tako osjećaju ponos i pružaju potporu članu obitelji koji je gorski spašavatelj. Zaključak istraživanja ukratko daje naslutiti da Gorska služba upotpunjuje spašavatelja na osobnom planu i posebno kao stručnjaka, a on istodobno obogaćuje stanicu kojoj pripada. Na taj se način prožima i povezuje ljudski s društvenim kapitalom. Dodatno, gorski spašavatelji shvaćaju članstvo u HGSS-u kao dio identiteta, to jest članstvo u HGSS-u vide kao poziv za služenje drugome i cjelokupnoj zajednici.

Uz pomoć kombinacije saznanja dobivenih uporabom desk metode i rezultata istraživanja u radu je također istaknuta rasprava i potreba za oblikovanjem novih javnih politika koje će u obzir uzeti moguće scenarije razvoja i izazove $s$ kojima se susreću gorski spašavatelji. Naime, gorske su službe diljem Europe i svijeta prvotno uspostavljene upravo kao službe spašavanja čiji su članovi planinari-volonteri, a osnovna im je zadaća bila pomoć i spašavanje u brdsko-planinskim područjima. U međuvremenu se mijenja stupanj prihvatljive razine rizika u društvu. Slijedom toga procesa dolazi do promjene legislative, odnosno dolazi do proširenja područja djelovanja gorskih službi. Ukratko, država blagostanja ili socijalna država slabi te se sve više odgovornosti prebacuje na civilno društvo. U tom je smislu određeni dio odgovornosti prebačen i na gorske službe spašavanja. To znači da gorski spašavatelj osim u planini i na nepristupačnim, ruralnim prostorima sada spašava i u gradovima, na vodi, traži nestale osobe; širi se djelokrug njegova rada i posljedično odgovornosti. Zbog toga, konkretno u Hrvatskoj, govorimo o dvama osnovnim izazovima s kojima se susreće HGSS. Prvi se odnosi na dilemu oko profesionalizacije Gorske službe ili njezina daljnjeg razvoja u sklopu civilnog sektora. Drugi se odnosi na način financiranja Službe. Ovdje također možemo govoriti i o dvama osnovnim scenarijima za budućnost. Prvi je da način pružanja besplatne pomoći ostane isti ili sličan sadašnjem, da organizacija dalje nastavi na temeljima volonterstva, odnosno dobrovoljnog rada i civilnog ustroja. Drugi se odnosi na daljnju institucionalizaciju i profesionalizaciju Službe, gdje bi misija gorskog spašavatelja postala profesija, a spašavanje i dalje besplatno. Međutim, postoji i treći, hibridni scenarij. U slučaju (polu)profesionalizacije država preuzima financiranje Službe, a taj je izdatak znatno veći od dosadašnjeg. Takav scenarij najvjerojatnije pretpostavlja uvođenje naplate određenih tipova spašavanja. Navedeni scenariji daljnjeg razvoja i izazovi s kojima se već danas susreće Gorska služba u Hrvatskoj svakako 
bi trebali imati utjecaja na kreiranje pomno osmišljenih, potrebama društva rizika prilagođenih javnih politika, osobito ako u obzir uzmemo kriznu situaciju u kojoj su se Hrvatska, Europa i svijet našli tijekom 2020. godine, a u kojoj službe poput HGSSa imaju jednu od ključnih uloga.

\section{Literatura}

1. Abercrombie, N.; Hill, S. i Turner, B. S. (2008). Rječnik sociologije. Zagreb: Naklada Jesenski i Turk.

2. Atkinson, R. (2002). The Life Story Interview, in: Gubrium, J. F. and Holstein, J. A. (Eds.). Handbook of Interview Research: Context and Method. Thousand Oaks, CA: Sage.

3. Bąk, R. and Kalina, R. M. (2016). Empirical justifying the possibility of educating specialists of the mountain rescue on subject of the medical rescue - example of Poland. SMAES, 12(1): 131-135. http://smaes.archbudo.com/view/abstract/ id/11369. (Pregledano 26. veljače 2020.)

4. Beck, U. (1992). Risk Society, Towards a New Modernity. London: Sage Publications.

5. Bušljeta Tonković, A. (2015). Održivi razvoj Središnje Lika - Prinosi analizi ljudskog i socijalnog kapitala. Zagreb - Gospić: Institut društvenih znanosti Ivo Pilar i Državni arhiv u Gospiću.

6. Cifrić, I. (2012). Leksikon socijalne ekologije: kritičko promišljanje. Zagreb: Školska knjiga.

7. Ćulum, B. (2008). Zašto i kako vrednovati volontiranje? Analiza modela institucionalnog priznavanja volontiranja kao preduvjeta za dugoročni razvoj kulture volontiranja i ostvarivanja prednosti u korištenju usluga ili kod zapošljavanja. https:// www.academia.edu/1334478/\%C4\%86ulum B. 2008 . Za\%C5\%A1 to i kako vrednovati volontiranje Zagreb Ministarstvo obitelji branitelja i me\%C4\%91ugeneracijske solidarnosti. (Pregledano 18. Veljače 2020).

8. Čaldarović, O. (1994). Socijalna teorija i rizici. Revija za sociologiju, 25 (3-4): 213-226. https://hrcak.srce.hr/154851. (Pregledano 25. veljače 2020.)

9. Geiger, M. (2009). S onu stranu monokulture: tradicijska znanja o okolišu i mreža života. Zagreb: Izdanja antibarbarus.

10. Giddens, A. (2005). Odbjegli svijet. Zagreb: Naklada Jesenski i Turk.

11. Giddens, A. (2007). Sociologija. Zagreb: Nakladni zavod Globus.

12. Juzbasic, M. i Vukasovic Hlupic, T. (2015). Osobine ličnosti i motivi za volontiranje. Psihologijske teme, 24 (2): 279-304. https://hrcak.srce.hr/142132. (Pregledano 27. veljače 2020.)

13. Kienholz, H.; Krummenacher, B.; Kipfer, A.; Perret, S. (2004). Aspects of Integral Risk Management in Practice - considerations with Respect to Mountain Hazards in Switzerland. https://pdfs.semanticscholar.org/68c7/05b02b52451d7ebf 1f5cf6680c7811a15a11.pdf. (Pregledano 21.veljače 2020.) 
14. Klaić, B. (1978). Rječnik stranih riječi. Zagreb: Nakladni zavod MH

15. Miljković, D. i Jurčec, L. (2015). Povezanost pristupa sreći, motiva za volontiranje i subjektivne dobrobiti volontera. Napredak, 156 (1-2): 115-129. https:// hrcak.srce.hr/166160. (Pregledano 5. ožujka 2020.)

16. Murray, M. (2018). Narrative Data, in: Flick, U. (Ed.). The SAGE Handbook of Qualitative Data Collection. SAGE Publications Ltd. doi: 10.4135/9781526416070.n17

17. Nichols, G. S.; Goel, R.; Nichols, T.; Jones, W. (2014). Volunteers in British Mountain Rescue: responding to increasing demand for rescues and a changed relationship with the state. Voluntary Sector Review, 5 (2): 213-230. http:// dx.doi.org/10.1332/204080514X14019726647694

18. Orlić, O. (2019). Antropologija solidarnosti u Hrvatskoj: poljoprivreda potpomognuta zajednicom. Zagreb: Biblioteka HED.

19. Pope, K. and Martin, S. R. (2011). Visitor Perceptions of Technology, Risk, and Rescue in Wilderness. International Journal of Wilderness 17 (2): 19-26.

20. Prebilič, V. and Svete, U. (2020). New Challenges and Possible Reorganization of Slovenian Mountain Rescue Service. https://www.researchgate.net/publication/267236805. (Pregledano 18. ožujka 2020.)

21. Rapley, T. and Rees, G. (2018). Collecting Documents as Data, in: Flick, U. (Ed.). The SAGE Handbook of Qualitative Data Collection. SAGE Publications Ltd. doi: http://dx.doi.org/10.4135/9781526416070.n24

22. Statut Hrvatske gorske službe spašavanja (2018). Vijeće stanica Hrvatske gorske službe spašavanja.

23. Šalaj, B. (2007). Socijalni kapital: Hrvatska u komparativnoj perspektivi. Zagreb: FPZ.

24. Šuperina, M. i Pogačić, K. (2007). Učestalost Hrvatske gorske službe spašavanja u traganju za nestalim osobama. Policija i sigurnost, 16 (3-4): 235-256. https:// hrcak.srce.hr/79264 (Pregledano 7. ožujka 2020.)

25. Tabak, E. i Kukić, D. (2018). Akter-mreža teorija. Alternativni pristup razumijevanju tržišta. Filozofska istraživanja, 38 (3): 527-538. https://doi.org/10.21464/ $\underline{\text { fi38305 }}$

26. Yarwood, R. (2010). Risk, rescue and emergency services: The changing spatialities of Mountain Rescue Teams in England and Wales. Geoforum 41: 257270. http://www.sciencedirect.com/science/article/pii/S0016718509001298. (Pregledano 20. siječnja 2020.) 
Izvorni znanstveni rad

\title{
An Analysis of the Mountain Rescue Responder's Role Using the Risk Society Concept: A Case Study of the HGSS Gospic Station
}

\author{
Anita Bušljeta Tonković \\ Institute of Social Sciences Ivo Pilar, Regional Center Gospić, Croatia \\ e-mail: anita.busljeta.tonkovic@pilar.hr
}

\begin{abstract}
The purpose of this paper is the analyse the role of the mountain rescue responder in contemporary risk society, using the example of the Gospić Station of the Croatian Mountain Rescue Service (Hrvatska gorska služba spašavanja - HGSS). Using the precepts of risk sociology as a platform, specifically the theory of a risk society that systematically generates risky situations and creates global environmental threats, and with the additional help of a combination of selected elements of the actor-network theory and the concepts of solidarity and volunteerism, the paper constitutes an attempt to comprehend a facet of the social reality confronted by the rescue responder by composing something of a sociological bricolage. The semi-structured interviews with narrative segments contained in the paper serve to present the preliminary research results (the interaction between the mountain rescue responder, his/her gear and the search dog; the continuity and characteristics of functioning in a risk society; the experience of action - solidarity; the experience of one's own role - volunteerism; the role of the Station and the HGSS as a whole - service; expanding the role of the HGSS), which may have some impact on the formulation of public policies directly linked to the theme of transferring the responsibilities of the welfare state to the domain of the civic sector. Briefly, the focus of this paper is the HGSS as one of the key actors in the civil defence system, i.e., mountain rescue responders as the primary protagonists in all search and rescue activities which proceed in mountainous, rural and remote areas.
\end{abstract}

Key words: risk society, mountain rescue responder, HGSS (Croatian Mountain Rescue Service), solidarity, volunteerism. 